\title{
Estimation of Strength by Partially Replacing Fine Aggregate with Saw Dust
}

\author{
R. Chitra, K. Sathish Kumar, S. Thendral
}

\begin{abstract}
This paper speaks to the aftereffects of the examination did from the utilization of considered residue to be incomplete swap for fine total in concrete.Saw dust is a side-effect of cutting penetrating or generally coming about because of the mechanical milling.In this fine total was supplanted by considered residue to be 0\%,5\%,10\%,15\% by weight for M-20 Mix.The solid $3 D$ shapes were tried for compressive quality at 7 years old days and 28 days.The result got was contrasted and typical solid M-20 Mix.The result shows that compressive quality declines as the saw residue pecrcentage increases. Optimum supplanting of sand with saw dust was seen as $15 \%$.
\end{abstract}

Keywords - Concrete, saw dust, ordinary portland cement, compressive strength

\section{INTRODUCTION}

Concrete is important in present day society's enthusiasm with new streets, industry, structures and different developments. Concrete has boundless open door for cutting edge application structure and development method[1]-[3]. It is the material of decision where quality, execution, imperviousness to fire, sturdiness is required. Concrete with the cutting edge innovations, for example, fortify bond cement and fiber fortified concrete gives additional quality and sturdiness against sliding breaking clasping and upsetting. Its high compressive quality and mouldability gives its far reaching use in different constructional. Solid properties can be improved by utilization of mechanical and household waste, for example, rice husk debris, timber debris, steel fibers,glass filaments and so on. In this paper saw dust debris was utilized as prime material for the improvement of the compressive quality of cement at age of 7 and 28 days of restoring period[4]-[5].

\section{MATERIALS USED}

A. Saw Dust

Saw Dust used in this study was collected from local mills. Specific gravity of sawdust is 2.12

Revised Manuscript Received on October 22, 2019.

R. Chitra, Department of Civil Engineering, Bharath Institute of Higher Education and Research, Chennai , India. Email: chitraroopauma@gmail.com

K. Sathish Kumar, Department of Civil Engineering, Bharath Institute of Higher Education and Research, Chennai , India. Email: sathish_4549@yahoo.co.in

S. Thendral , Department of Civil Engineering, Bharath Institute of Higher Education and Research, Chennai , India. Email: thendral.cs@gmail.com
Table:1 Chemical properties of saw dust

\begin{tabular}{|c|c|}
\hline OXIDE & $\begin{array}{c}\text { PERCENTAGE (BY } \\
\text { WEIGHT) }\end{array}$ \\
\hline $\mathrm{SiO}_{2}$ & 68.3 \\
\hline $\mathrm{Al}_{2} \mathrm{O}_{3}$ & 3.5 \\
\hline $\mathrm{Fe}_{2} \mathrm{O}_{3}$ & 2.23 \\
\hline $\mathrm{MgO}$ & 5.4 \\
\hline $\mathrm{CaO}$ & 5.0 \\
\hline
\end{tabular}

B. Cement

Concrete utilized in this test was 43 evaluation conventional Portland bond affirming IS-8112:89.

Table:2 Physical properties of Cement

\begin{tabular}{|c|l|l|}
\hline $\begin{array}{l}\text { S1. } \\
\text { No }\end{array}$ & Characteristics & Values \\
\hline 1 & Specific gravity & 3.12 \\
\hline 2 & Normal consistency, percent & 37 \\
\hline 3 & Initial setting time, minutes & 55 \\
\hline
\end{tabular}

\section{Fine Aggregate}

The fine total utilized was gathered from locally accessible destinations and affirmed into zone-3 of IS 383:1970.

Table:3 Physical properties of Fine Aggregate

\begin{tabular}{|c|l|l|}
\hline $\begin{array}{c}\text { S1. } \\
\text { No }\end{array}$ & Characteristics & Values \\
\hline 1 & Specific gravity & 2.55 \\
\hline 2 & Fineness modulus & 3.25 \\
\hline 3 & Water absorption & 105 \\
\hline
\end{tabular}

\section{Coarse Aggregate}

The coarse total utilized was gathered from locally accessible spots having size 20mm and affirming to IS 183:1970.

Table:4 Physical properties of Coarse Aggregate

\begin{tabular}{|c|l|c|}
\hline $\begin{array}{c}\text { S1. } \\
\text { No }\end{array}$ & Characteristics & Values \\
\hline 1 & Specific gravity & 2.71 \\
\hline 2 & $\begin{array}{l}\text { Aggregate impact } \\
\text { value,percent }\end{array}$ & 23.9 \\
\hline 3 & Los Angels,percent & 12.85 \\
\hline
\end{tabular}

\section{E. Water}

The Water utilized here was compact water and was spotless without having any unmistakable polluting influences. 


\section{EXPERIMENTAL PROCEDURE}

\section{A. Mix Design}

M20 evaluation of cement was intended for this test with blend extent of 1:1.60:2.78 in with water concrete proportion 0.45 . The solid blend configuration has been structured dependent on IS 10262:2009 [6]-[9]

\begin{tabular}{|c|c|c|c|}
\hline Water & Cement & $\begin{array}{c}\text { Fine } \\
\text { aggregate }\end{array}$ & $\begin{array}{c}\text { Coarse } \\
\text { aggregate }\end{array}$ \\
\hline 0.45 & 1 & 1.60 & 2.78 \\
\hline
\end{tabular}

\section{RESULTS AND DISCUSSION}

The after effects of the compressive quality performed on the test tests as exhibited in the table 5 with different level of saw dust and distinctive number of days for restoring [10]-[11].

\begin{tabular}{|c|c|c|c|}
\hline $\begin{array}{c}\text { Cement } \\
\text { grade }\end{array}$ & $\%$ saw dust & 7 days & 28 days \\
\cline { 3 - 4 } & $\begin{array}{c}\text { compressive } \\
\text { strength } \\
\left(\mathrm{N} / \mathrm{mm}^{2}\right)\end{array}$ & $\begin{array}{c}\text { compressive } \\
\text { strength } \\
\left(\mathrm{N} / \mathrm{mm}^{2}\right)\end{array}$ \\
\hline M-20 & 0 & 9.67 & 25.41 \\
\hline M-20 & 5 & 11.08 & 24.20 \\
\hline M-20 & 10 & 10.98 & 23.75 \\
\hline M-20 & 15 & 7.88 & 17.54 \\
\hline
\end{tabular}

Table: 5 Compressive Strength of cubes with various percentage of saw dust and days of cure

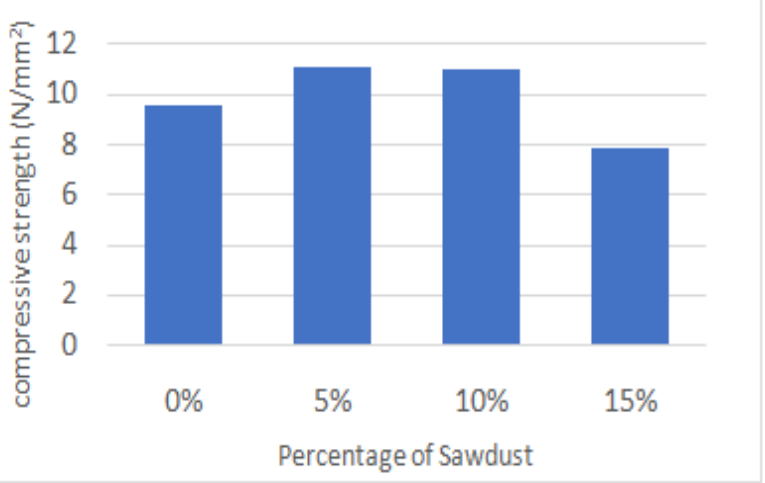

Figure: 1 Compressive strength of the Cubes for 7 days

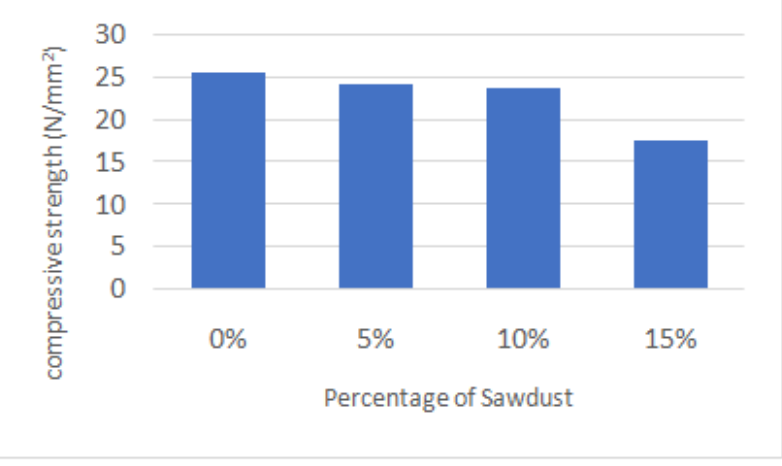

Figure:2 compressive strength of cubes for 28 days

\section{CONCLUSION}

Followingpoints are observed in the current study

- The use of saw dust in concrete gives extra natural just as specialized advantages for every single related industry

- Partial substitution of saw sawdust decreases the expense of making concrete [12]-[13]

- Water ingestion expanded with expanding saw dust rate

- To accomplish a superior outcome sawdust, supplant with fine total by $10 \%$

\section{REFERENCES}

1. Sathish Kumar, K., Vinothkumar, S., Venkatakrishnaiah, R. \& Mohan, S.J. 2019, "Experimental investigation on rehabilitation of corroded concrete beam specimens", International Journal of Civil Engineering and Technology, vol. 10, no. 1, pp. 2949-2955.

2. Kanchanabhan, T.E., Krishnaiah, R.V., Dayakar, P. and Mani, A., 2019. A detailed study on green building concept in construction industry. International Journal of Civil Engineering and Technology, 10(1), pp. 2944-2948.

3. Mugilvani, P., Murugan, S.T., Kaviya, B. and Sathishkumar, K., 2019. Experimental investigation on nano concrete. International Journal of Civil Engineering and Technology, 10(1), pp. 907-912.

4. Vinothkumar, S., Sathishkumar, K., Anish, C. and Rajesh, S., 2019 Characteristic strength of concrete by partial replacement with sawdust and waste ceramic tiles. International Journal of Civil Engineering and Technology, 10(1), pp. 2821-2829.

5. Chitra, R., Thendral, S., Arunya, A. and Mohan, S.J., 2019. Experimental study on strength of concrete by partial replacement of fine aggregate with saw dust. International Journal of Civil Engineering and Technology, 10(1), pp. 2766-2769.

6. Mani, A., Meikandaan, T.P., Gowrishankar, P.G. and Kanchanabhan, T.E., 2019. A study on treatment of industrial effluent (dyeing) using moringa oleifera, tamarina indica as coagulants. International Journal of Civil Engineering and Technology, 10(1), pp. 2796-2811.

7. Frank Stephen, S., Chockalingam, M.P., Nalanth, N. and Lekshmy Raghavan, P., 2019. Study on the fresh state properties of self compacting concrete modified with recycled concrete aggregate. International Journal of Civil Engineering and Technology, 10(1), pp. 1205-1212.

8. Dayakar, P., Raman, K.V., Arunya, A. and Venkatakrishnaiah, R., 2019. Study on strength properties of sand by biocementation with eggshell. International Journal of Civil Engineering and Technology, 10(1), pp. 2770-2785. 
9. Shendge, R.B., Chockalingam, M.P., Saritha, B. and Ambica, A., 2018. Swat modelling for sediment yield: A case study of Ujjani reservoir in Maharashtra, India. International Journal of Civil Engineering and Technology, 9(1), pp. 245-252.

10. Meikandaan, T.P. and Hemapriya, M., 2017. Use of glass FRP sheets as external flexural reinforcement in RCC Beam. International Journal of Civil Engineering and Technology, 8(8), pp. 1485-1501.

11. Harini, A.T., 2017. Experimental study on utilisation of ceramic wastes in concrete. International Journal of Civil Engineering and Technology, 8(8), pp. 1346-1352.

12. Ambica, A., Sartiha, B. and Anbarasan, R., 2017. Groundwater quality assessment using water quality index and GIS, Maduravoyal, Chennai, India. International Journal of Civil Engineering and Technology, 8(8), pp. 1375-1381.

13. Aswathy, M., Saritha, B. and Chockalingam, M.P., 2019. Degradation of anionic dye using $\mathrm{Fe} / \mathrm{Tio} 2$ composite by photocatalysis. International Journal of Innovative Technology and Exploring Engineering, 8(9 Special Issue 3), pp. 788-791

\section{AUTHORS PROFILE}

R. Chitra Assistant Professor, Department of Civil Engineering, Bharath Institute of Higher Education and Research, Chennai, India.

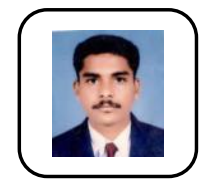

K. Sathish Kumar Assistant Professor, Department of Civil Engineering, Bharath Institute of Higher Education and Research, Chennai , India.

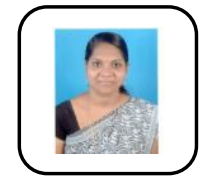

S. Thendral Assistant Professor, Department of Civil Engineering, Bharath Institute of Higher Education and Research, Chennai , India. 